\title{
Aligning the Working Needs of Teachers to Continuous Professional Development Programmes in the Nanumba North District of Ghana: Interrogation within the Ambience of Policy and Practice
}

\author{
A. Mahama, M. Issah, and I. M. Gunu
}

\section{ABSTRACT}

\begin{abstract}
Professionals all over the world including teachers need to update their knowledge and skills often through diverse Continuous Professional Development Programmes (CPDP's). Using the Descriptive Survey Design and Mixed Method Approach, this paper assesses the policy requirements and the potency of these training programmes in relation to the working needs of teachers within the Nanumba North District of the Northern Region of Ghana. The study sampled 100 teachers and 20 administrators in various Basic Schools in the district. Mainly, questionnaires and in-person interviews were used in soliciting data. Data management and analysis in this study was done using the SPSS version (23). Even though the study did not entirely dismiss the fact that the Ghana Education Service appreciates the importance of CPDP's, the findings strongly revealed that CPDP's in the district do not align with the working needs of participating teachers. Organizers choose areas they deem important without conducting needs assessment for training engagements. It is recommended that CPDP's must be incorporated into the teacher training curriculum and backed by law and thus support and address the operational needs of the Ghanaian teacher.
\end{abstract}

Keywords: Continuous Professional Development Programmes, Working Needs, Teachers, Alignment, Policy, and Practice

\section{INTRODUCTION}

Teachers are a necessity and their roles are paramount for any educational system to thrive and achieve its goal. The quality of teacher training and the continuous professional growth are essential to ensure that education systems reap the full potential of teachers' contribution to education.

Morrison (2009) defines professional development as a continuing process from which we get skills, knowledge, and abilities that must be related to our job responsibilities through work requirement and profession.

The wave of educational policy changes has exposed the outmoded one-stop induction and orientation for teachers when they newly join the profession, and strongly argue that training for professional teachers must be continuous for purposes of adapting new skills and competences for better teaching and learning.

Continuous professional development of teachers seeks to patch gaps emanating from the disconnect between theory and content that is taught at colleges and actually navigating the challenges of the real classroom situation (Jarvis \& Algozzine, 2006).

Teachers learn content and general methods of teaching in training schools, on the field empowerment in terms of
Published Online: January 6, 2022

ISSN: $2736-4534$

DOI : 10.24018/ejedu.2022.3.1.242

\section{Alhassan*}

University for Development Studies, Faculty of Education, Department of Educational Foundations Studies,

Ghana.

(amahama@uds.edu.gh)

I. Mohammed

University for Development Studies, Faculty of Education, Department of Business Education Studies, Ghana. (ssh.mohammed@yahoo.com)

I. M. Gunu

University for Development Studies, Faculty of Education, Department of Educational Management and Policy Studies, Ghana.

(igunu@uds.edu.gh)

*Corresponding Author

career development taken into consideration their working needs are ignored. According to Moyle (2007) it is ideal to regularly update teachers professional competencies, taken into consideration their individual needs, this will improve capabilities of teachers and eventually lead to desirable learning outcomes of learners.

According to Adu-Gyamfi et al. (2016), Ghana has gone through series of educational reforms, persistent modification of educational reforms in Ghana anytime there is a change in government in the quest to make education quality, accessible and to meet the demands of individuals of the society. These reforms in contemporary Ghana include Free Compulsory Universal Basic Education (FCUBE) that addresses the quality concerns in iasic education, and Free Senior High School (FSHS) policy all geared towards creating an educated society.

Humphrey (2014) believes that the institutionalization of CPDP's providing regular and relevant training for teachers, aside the initial training they receive from colleges and universities will create a competent teaching force.

The professional development of teachers is therefore more successful when it is explicitly linked to the working needs of the teacher and classroom lessons. It is therefore imperative that the needs of teachers must be 
assessed and captured in planning and delivering professional development programmes.

\section{StAtement OF PROBlem}

Education in Ghana has gone through series of reviews and restructuring. The entire process misses a fundamental component of clear cut policies that require that training institutions and the government offer a range of Continuous Professional Development Programmes that address the working needs of teachers.

This will ensure that teachers effectively discharge their duties and more importantly adhere to the standards set to govern the development and management of teachers, drawing on the 2008 Education Act, which established the National Teaching Council (NTC) clothed with the obligation for setting expert standards and etiquette, registration and accrediting teachers.

Until 2018, licensing of teachers was not a priority on the table of policy makers.

The NTC sets the framework for employment of teachers, provides in-service education and training (INSERT) and conducts periodic review of professional practices and ethical standards for teachers and teaching (MoE, 2012). An informal conversation with some classroom teachers and head teachers in the Nanumba North District revealed that no effective instruction and learning is going on at the stateowned basic schools, performance levels in the Basic Education Certificate Examination (BECE) recently have not been encouraging, and teachers still use traditional delivery methods in the classroom. The teaching profession according to them does not allow or inspire individual professional development.

It is perceived that apart from the training they received at the universities/colleges, no further professional development programmes have been given to them. This they said may lead to attrition and turn-over. Teachers in the area believe they need to be properly trained to compete with colleagues anywhere across the globe.

But there is still a wider gap in terms of access to higher degree programmes and professional development opportunities between the teachers in the area and those in urban parts of the country.

It is therefore vital to appraise how CPDP's addresses the professional needs of teachers at the basic schools in the Nanumba North District, its effectiveness on teaching and learning, and make recommendations to appropriate authorities.

In addition, the study will provide basis for further policy engagements and studies with regard to teachers' continuous professional development.

\section{PReParing the GHANAIAN Classroom Teacher}

In the developing world especially Ghana, sustainable development rides on the back of quality education. In meeting the escalating demand of education for all, several flagship interventions are rolled out by subsistent governments to enormously enhance the provision of education (e.g., FCUBE, Free SHS, GETFUND
Scholarships and Projects). With all these efforts, technology and infrastructure still remains inadequate, making the teacher the centre of every learning experience.

In different significant ways, quality teachers impact greatly on students' achievement (Alliance for Excellent Education, 2006). Recently, several studies have revealed that the most significant variable in student success is a properly trained and competent teacher. Teachers must go through some level of professional training to be able to assume roles in the classrooms.

Professional teacher training institutions should train educational frontrunners taken cognizance of the developmental and educational needs of children (Israel et al., 2014). In the case of Ghana, teacher training schools and universities (UDS, UCC, UeW etc) mandated to train professional teachers must assess the needs of teachers as well as that of learners they will come into contact with.

Ethics and professional conduct must be encapsulated in the gene of the teachers under training, so as to deliver effectively on the job. Varied theoretical views reflect different understanding of teaching and learning and suggest different ways to prepare novice teachers and even those already on the job.

Research suggests that more qualified teachers must be recruited, constantly trained on the job and retained since it is essential for the success of any educational system.

Again, teacher training should seek to improve student achievement and scrutinize the impact of teacher training with time, as well as establish the connections between teacher training, orientation programs, and continuous professional development opportunities (Wilson et al., 2001). In an ideal situation, student learning must remain the vital goal of teacher training. Teachers must be able to help students achieve academically (Riehl et al., 2000)

Teachers' preparedness is a matter of concern, the level at which teachers felt adequately trained upon entering the teaching profession should significantly correlate with their sense of responsibility for student learning, sense of teaching efficacy and their plans to remain in teaching (Darling-Hammong et al., 2002). Teachers in the Nanumba North District must be given a chance to develop their expertise and knowledge in order to remain relevant in the classroom.

\section{CONCEPT AND MEANING OF CONTINUOUS PROFESSIONAL DEVELOPMENT}

Professional development is a continuing process where teachers are offered skills, knowledge and special abilities related to their profession, job description and requirement. Shoqair and Shaaban (2013) postulated that the contemporary teacher needs to undertake lifelong educational learning programs that seek to prepare teachers to be abreast with the ever changing academic field.

Guskey (2002) says that specialized improvement programmes are ordered exertions sort to stimulate the performance of classroom teachers and desired learning results of students. Professional development can also mean the provision of a well-developed systematic learning process that will eventually empower the teacher adequately 
to perform on the job. When teachers are trained professionally, they deliver well in class and students achieve academically.

Hassan (2013) stated that continuous professional development programmes are not a collection of lonely presentations given by professionals and mentors; it encompasses effective operation of professional development including induction trainings as well as plans for continuing, mentoring, augmentation and follow up learning. Continuous Professional Development (CPD) means endlessly improving teachers expertise and efficacy to ensure efficiency, manifesting in ways of improving the general quality of teaching and education (Ethiopian Ministry of Education, 2005).

A research conducted by Bredeson (2003) suggests that professional development (PD) should prioritize addressing the specific needs of teachers. It should be an unbroken process, in order to successfully contribute to the general improvement of education.

The concept of teacher's continuous professional development today places more emphasis on preparing school teachers in both pedagogy and academic content. The teacher's work in recent times has undergone tremendous change, presupposing that the classroom teacher needs more in order to keep up with rapid changes and remain relevant in the teaching profession (Ndeto \& Bwisa, 2013).

It is incumbent on teachers to train on-the-job either contractually or by certification; they must participate in CPDP's to become improved educators. Continuous professional development should therefore afford teachers a good opportunity to effectively apply their freshly attained knowledge into practice.

Since teaching is complex and changes with time, teachers must be well positioned to adequately satisfy the diverse needs of the students' population. Professional development, also called professional learning or continuing education, is a major tool for providing students adequate learning (National Education Association, 2010). Moreover, it plays an important role in building fully trained knowledgeable and motivated employees.

According to Day and Sachs (2004), the main drive of CPD programmes is to offer a support system for teachers wherever they teach. This will make them outstanding and clothed with strong commitment, competence and confidence to teach.

\section{Benefits of CONTINUOUS PROFESSIONAL DEVELOPMENT TO TEACHERS}

Indeed, there has been growing attention about the vital role of professional development programmes in aiding teachers to manage the complexities and difficult demands of the teaching profession. Several studies illuminate a range of challenges the teaching profession faces, the changing role of today's teachers; being reflective and forward planning is the main focus in the provision of quality education.

According to Hammerness et al. (2005), teachers' have dissimilar needs at different stages of the profession. Professional development of teachers is fundamental and must take cognizance of the varying needs of the classroom and the whole of the teaching fraternity.

In the discussions of Ndeto and Bwisa (2013), when extra prominence is placed on preparing teachers in both content and pedagogy because the work of the teacher today has experienced tremendous transformation, the teacher thus become well equipped in order to keep up with the swift changes within the profession of teaching.

Turner-Bisset (2001) argued that unlike the past, today the industry of teaching has become progressively difficult; teachers must therefore be current and follow trends to remain relevant. Today's teachers must therefore cultivate the habit of learning in their everyday classrooms in order to remain relevant.

\section{OBJECTIVES OF THE STUdY}

This study;

a). Examines how often teachers in the Nanumba North District have access to CPDP's.

b). Ascertain the extent to which CPDP'S addresses the working needs of teachers in the Nanumba North District.

c). Explores mechanisms adopted to enhance the Continuous Professional Development of teachers in the Nanumba North District.

\section{Methodology}

The study used adequate approaches to solicit and analyze data as well as interpretation and discussion. Also in this part constitute Target Population of the study, Data Collection Procedure, Sample and Sampling Technique and Research Instruments.

\section{A. Target Population}

The target population comprised One hundred (100) classroom teachers and twenty (20) head teachers of the twenty (20) selected Basic School of the Nanumba North District. The table below shows the detail breakdown of the research participants:

\begin{tabular}{cccc}
\multicolumn{4}{c}{ TABLE I: BREAKDOWN OF RESEARCH RESPONDENTS } \\
\hline \hline Respondents & Male & Female & Total \\
\hline Teachers & 58 & 42 & 100 \\
Head Teachers & 12 & 8 & 20 \\
\hline \hline
\end{tabular}

\section{B. Sample and Sampling Technique}

The sample for the study was drawn from 20 Basic Schools from the twelve (12) Education Circuits within the Nanumba District. In total, one hundred (100) teachers and twenty (20) headmasters were selected for the study.

\section{Sampling Technique}

Taking a cursory look at the schools within the circuit, some circuits had more schools than others. Simple Random Sampling technique was used in selecting the one hundred (100) teachers to avoid biases.

According to Hallberg (2013), the quality and adequacy of a population sample has a direct effect on the quality of the research generalizations. Head teachers were purposefully sampled owing to the role they play as 
planners, supervisors and implementers of various forms of Continuous Professional Development Programmes for teachers.

\section{Research Design}

This study employed the Descriptive Survey Design. Many researchers have built consensus that the descriptive design establishes the current state and nature of a particular phenomenon, as it occurs at the period of a study (Fraenkel $\&$ Wallen 2006). Hence this study leverages on the strength of this design.

\section{E. Data Gathering Instruments}

A questionnaire was used to gather data on aligning the work needs of teachers to continuous professional development programmes in the Nanumba District. One hundred (100) questionnaires and interview guides were used in the data gathering process. Items in the questionnaire employed a Likert-type respond scale. A fivepoint scale was used to avoid neutral response patterns. A five-point scale also seemed more appropriate for Basic School Teachers. In order to avoid repetition in the presentation of the response alternatives and to control teachers selecting the same response for each item, the response were put in a table form to guide teachers in selecting the responses. Likert scale of the five responseb. categorized as: Strongly Agree, Neutral, Disagree and Strongly Disagree.

A semi- structured interview guide was constructed to collect further information on the study. A concise interview schedule was designed by the researchers. According to Adams (2015), respondents must be asked the same questions, to allow objectives comparison of the results. The researcher designed the interview schedule free from bias and administered to all the respondents to ensure consistency of responses.

\section{F. Data Collection Procedure}

Administering the Research Questionnaire: The data for the study was gathered by the researcher using the questionnaire within a period of one month. The questionnaire was handed to 100 teachers in the district, and recovered at different times.

Conduct of Interview Sessions: Interview sessions were held on one-on-one interaction with the head teachers. Sessions were audio-recorded with prior consent of the respondents. According to Hancock et al. (2007) recording interviews allows for lengthy engagement between the researcher and the interviewee in an "informal and semistructured interview taking verbatim excerpts in a natural conversational flow".

\section{G. Analysis and Management of Research Data}

Quantitative data collected via the use of questionnaires were coded, entered and analyzed using descriptive statistics; Excel and Statistical Package for Social Scientist (SPSS).

Qualitative data from interviews were also transcribed and reported as such for the purpose of answering the research questions. This qualitative analysis was done manually using thematic methods. Vast data collected from different sources was reduced and interpreted to shed more light on the study.

\section{H. Validity and Reliability of the Research}

A pilot testing was carried out on the instrument using 10 head teachers and 50 classroom teachers in the Gonja East District of the Savannah Region, which is actually not the research area. This was done in order to ensure that the instrument is fit for the study and devoid of ambiguity.

The pilot study however revealed the ambiguity of some items and the need to reconstruct them to ensure better understanding of all participants. The researcher however effected all corrections coming from the pilot study to ensure that it measures what it is supposed to measure.

\section{RESUlTS AND DiscUSSIONS}

In achieving the purpose of the study, data realized from the field was processed and presented in frequencies, mean, median and percentages below;

Results and findings of the study stemmed out of the field data (2021). Discussions were done in relation to the research questions;

1. How often do teachers in the Nanumba North District have access to CPDP's?

2. To what extent do CPDP's addresses the working needs of teachers in the Nanumba North District?

3. What mechanisms can be adopted to enhance the Continuous Professional Development of teachers in the Nanumba North District?

\section{A. Biographical Respondent Information}

The study revealed that most of the respondents were male $(52 \%)$ whilst females constituted only $(42 \%)$. The age distribution specifies that majority of the research respondents are within the ages of 40-49 representing $41 \%$ of the total respondents. It was also disclosed that $40 \%$ of the teachers had between 1-5 five years teaching experience indicating that majority of the teachers in the study were novice and returnees of further studies from tertiary institutions.

Majority of the classroom teachers in the study schools, representing 58\% were Senior Superintendents II, seven (7) percent of the teachers were Superintendent I, and 35\% were Principal Superintendents. This confirms the fact that teachers in the selected schools were either new on the job or had just come back from pursuing higher degrees.

\section{B. Teachers Access to Continuous Professional Development Programmes}

The table below (Table II) shows reactions in response to the frequency at which teachers in the Nanumba North District access CPDP's; quite a significant percentage of the teachers, representing $61 \%$ said they attend training programmes once in a year, while $14 \%$ said they attend training programmes once a term. However, $18 \%$ interestingly said they have never attended any training programme in the district. It appeared that majority of the respondents have attended training programmes, but not quite often. 
TABle II: How OfTEN Do TEACHERS TAKE PART IN ANY PROFESSIONAL DEVELOPMENT PROGRAMME IN THE DISTRICT

\begin{tabular}{ccc}
\multicolumn{3}{c}{ DEVELOPMENT PROGRAMME IN THE DISTRICT } \\
\hline \hline Item & Frequency & Percentage \\
\hline once a term & 14 & 14.0 \\
once in a year & 61 & 61.0 \\
twice in a year & 7 & 7.0 \\
not at all & 18 & 18.0 \\
Total & 100 & 100.0 \\
\hline \hline
\end{tabular}

Source: Field Data, 2021

Generally, the study shows that teachers do not have regular access to CPDP's in the Nanumba North District. Even though there are policy initiatives requiring teachers to regular update their knowledge, this arrangements are not discharged. Teachers usually would manage classroom in their own best way since training programme that would have equipped them with practical and recent knowledge is not available.

Mohammed (2015) conducted a study in South Africa which revealed that continuous professional development is key in developing the teacher, however, several barriers deny teachers the opportunity to update their knowledge on the job, and key amongst them is access. Majority of head teachers who partook in the study lamented about the erratic occurrence of professional teacher training programmes within the district.

The initial induction training/orientation is a policy demand offered to teachers. It remains the only time for some teachers in many years of services to be trained on the modus operandi of the teaching profession. Even in most cases in the district, teachers are not given any form of induction/orientation before they take charge of the classrooms, they wonder on the job on their own. This do not auger well for teaching as a profession. When teachers are adequately prepared, it provides an augmented capacity to teach better and boost their confidence.

Below are some qualitative responses from participants:

Respondent A:

They are not organized quite often, but sometimes within a year we could have up to two or three CPD programmes organized by GES and NALAP.

Respondent B:

The GES authorities do not organize them regularly; they do it once in a blue moon, so we don't have the opportunity to attend regularly.

Atta and Mensah (2015) maintained that professional development programmes in Ghana are only one irregular short occasional events targeted at updating teachers knowledge in critical teaching/learning areas which perhaps might not have been taught in the training school.

\section{To What Extent do CPDP'S addresses the Working Needs of Teachers in the Nanumba North District?}

Continuous Professional Development Programmes are a sure way to elevating the knowledge levels of teachers. It is important that on-the-job training is made mandatory at all streams of the Ghanaian teaching fraternity.

The research question two investigated the following assertions; CPD programmes increases and update teachers' knowledge on subject matter, CPD programmes familiarizes teachers with new educational technologies and safe educational practices, CPD's provide teachers with training, professional growth and promotion, CPD programmes boost the leadership and administrative competence of classroom teachers, Continuous Professional Development (CPD) is vital to advance the teacher's professional bearing so as to progress the quality of instruction and learning in the classroom.

Table III below shows some of the ways by which continuous professional development addresses the classroom needs of teachers. The letters of the alphabets used in the table below stand for the following:

$(\mathrm{N}=$ the total number, $\mathrm{M}=$ the mean value and $\mathrm{SD}=$ standard deviation).

TABLE III: EXTENT TO WHICH CPDP'S ADDRESSES THE WORKING NEEDS OF TEACHERS IN THE NANUMBA NORTH DISTRICT

\begin{tabular}{cccc}
\hline \hline Statement & $\mathrm{N}$ & $\mathrm{M}$ & $\mathrm{SD}$ \\
\hline $\begin{array}{c}\text { CPD programmes increases and update } \\
\text { teachers' knowledge on subject matter }\end{array}$ & 100 & 1.60 & 0.88 \\
$\begin{array}{c}\text { CPD programmes familiarizes teachers } \\
\text { with new educational Technologies and } \\
\text { safe educational practices }\end{array}$ & 99 & 1.85 & 0.94 \\
$\begin{array}{c}\text { CPD programmes provide teachers with } \\
\text { training, professional growth and } \\
\text { promotion }\end{array}$ & 100 & 1.68 & 0.95
\end{tabular}

CPD programmes boost the leadership and administrative competences of classroom teachers

$100 \quad 1.47 \quad 0.81$

CPD is vital to advance the teacher's professional bearing so as to progress the quality of instruction and learning in the classroom

$\begin{array}{lll}100 & 1.82 & 0.98\end{array}$

CPD is a necessary requirement for the quick development of relevant work skills

$100 \quad 1.52 \quad 0.80$

CPD programmes are necessary to update teachers on new theories, ideas and techniques that are extremely difficult for teachers to learn individually

$100 \quad 1.58 \quad 1.11$

Valid N (listwise)

99

Agree (N 1), Disagree (N 2), Strongly Agree (N 3), and Strongly Disagree (N 4)

In answering the research question, data from pupils' and teachers' questionnaires, interviews and observation were used.

The table reveals that on the average, teachers and head teachers in the Nanumba north district agree that CPD programmes are essential to the development of teachers if they are well designed and critically implemented.

The mean score of 1.60 and standard deviation of 0.88 indicate that when teachers attend CPD programmes, it increases and update their knowledge on the subject matter. They perform much better in the classroom than without consistent training.

The Institute for learning (2009) argued that professional development has to do with updating, maintaining and improving appropriate expertise and knowledge in a subject area or vocational field and in methods of instruction and 
training culminating into positive impact on the learner's experience and practice.

Again, the mean score of 1.85 and standard deviation of 0.94 indicate that since the advent of technology, research has shown that integrating technology into teaching improves learning. Teachers believe that if they are trained on-the-job to familiarize themselves with technology, and incorporate it into their teaching and learning, it will ensure safe educational practices and improve their performance in class.

Furthermore, on the issue of CPD programmes providing teachers with training, professional growth and promotion, majority of the respondents were of the same view, the mean of 1.68 and standard deviation of 0.95 confirms this assertion. This agrees with Hassan (2013) assertion that professional development programmes have significant impact on the quality of education delivered to the student because these training or other professional development programmes lead to the increase in teachers' knowledge to improve quality education.

However, the mean score of 1.47 and standard deviation of 0.81 indicate that when teachers and head teachers alike attend CPD programmes, it enhances their leadership and administrative competence. This helps them to go round their assign duties and offers support to others where necessary.

It is essential also to develop teachers' professional skills, knowledge and understanding so as to improve the quality of teaching and learning in the classroom. A mean score of 1.82 and a standard deviation of 0.98 confirm the claim. Similarly, the mean of 1.58 and standard deviation of 1.11 indicates strongly that CPD programmes open up teachers understanding of new theories, ideas and techniques and positions them comfortably to be reflective and learn everything independently.

Below are responses from participants regarding the above topic:

Respondent A:

To a large extent, Yes! appropriate methodology usage, appropriate use of TLMs in class, we teach in line with the curriculum, classroom management is enhanced, systematic presentation and it improves teachers performance productivity of teachers improved.

Respondent B:

It makes teachers more competent to handle a class confidently, Inspire teachers to work hard and promote effective teaching and learning, it enhance teachers to work within the range of time, it helps teachers to be self-oriented and it guide teachers to be up and doing.

According to Lindstrom and Speck (2004), professional development is a continual persistent practice of professional learning supported by current research and allows for suitable professional collaboration and knowledge sharing, to support based on current research to inform teachers' everyday routines.
D. Mechanisms to be adopted to enhance the Continuous Professional Development of Teachers in the Nanumba North District

The research question three investigated the following and is presented in the table below; the district outlined plans and taken pragmatic mechanisms to provide CPDP's, whether the district is waiting on the government and NGO's to address the situation of inadequate CPD programmes, the need to make professional development programmes compulsory for all teachers, teachers must be granted study leave in due course in the district and authorities must design and implement CPDP's that address the working and classroom needs of teachers.

TABLE IV: MECHANISMS TO BE ADOPTED TO ENHANCE THE CONTINUOUS PROFESSIONAL DEVELOPMENT OF TEACHERS IN THE NANUMBA NORTH

\begin{tabular}{|c|c|c|c|}
\hline \multicolumn{4}{|c|}{ DISTRICT } \\
\hline Statement & $\mathrm{N}$ & $\overline{\mathrm{M}}$ & 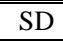 \\
\hline $\begin{array}{l}\text { The district outlined plans and taken } \\
\text { pragmatic mechanisms to provide } \\
\text { CPDP's }\end{array}$ & 100 & 2.29 & 0.95 \\
\hline $\begin{array}{l}\text { The district is working with NGO's } \\
\text { to overcome the challenges }\end{array}$ & 100 & 1.92 & 1.10 \\
\hline $\begin{array}{l}\text { The district is waiting on the } \\
\text { government to address the } \\
\text { inadequacy of CPDP's }\end{array}$ & 100 & 1.64 & 0.95 \\
\hline $\begin{array}{l}\text { The district's plans are short term } \\
\text { for improving CPDP's in the district }\end{array}$ & 100 & 2.15 & 1.20 \\
\hline $\begin{array}{l}\text { CPDP's must be institutionalized } \\
\text { and made compulsory for all } \\
\text { teachers in line with policy }\end{array}$ & 100 & 1.82 & 0.98 \\
\hline $\begin{array}{l}\text { Teachers must be granted study } \\
\text { leave in due time in the district }\end{array}$ & 100 & 1.52 & 0.80 \\
\hline $\begin{array}{l}\text { Authorities must design and } \\
\text { implement CPDP's that address the } \\
\text { working and classroom needs of } \\
\text { teachers }\end{array}$ & 100 & 1.58 & 1.11 \\
\hline $\begin{array}{l}\text { Teachers must be provided with } \\
\text { time and opportunity to acquire } \\
\text { knowled ge from colleagues both } \\
\text { within the workplace and outside } \\
\text { the workplace }\end{array}$ & 100 & 1.58 & 1.11 \\
\hline Valid N (listwise) & 99 & & \\
\hline
\end{tabular}

From the table above, the mean score of 2.29 and standard deviation of 0.95 shows that there is a wide variance between the mean and standard deviation. This indicates that majority of the respondent do not agree with the assertion that the district has plans and has taken appropriate steps to provide CPD programmes to teachers.

The preparation, enlistment and retaining of more competent educators are essential for the success of any educational system to thrive.

Israel et al. (2014) argued that professional teacher training institutions must take cognizance of the developmental and educational needs of children. Teacher training should therefore seek to improve student achievement and scrutinize the impact of teacher training with time, as well as establish the connections between 
teacher training, orientation programs, and continuous professional development opportunities (Wilson et al. 2001).

Again, the mean score of 1.92 and standard deviation of 1.10 indicate that since the district education directorate is relenting on its efforts to provide CPD programmes, NGO's in the area have done marvelously well over the years in addressing the learning needs of both teachers and students. Donor support is the main stern of CPD in some many districts including the Nanumba North District. The funding from donor agencies is usually inadequate and can only take care of few schools within these sections. The respondents thus agree that the efforts of the district are supplemented by NGO's and donors in the provision of training and development programmes to teachers within the district.

Acheampong (2004) confirmed that professional learning activities organized by the Education Ministry, Ghana Education Service, and other funding organizations takes the form of the cascade model of on-the-job training. School heads and circuit supervisors are firstly trained, and they are expected to in turn pass on the knowledge acquired through similar organized training workshops to local districts and schools. This does not address the working needs of beneficiaries; cogent steps must therefore be taken to address this.

A mean of 1.64 and a standard deviation of 0.95 establishes the fact that respondents are of the view that the district is not taken their own initiatives, but rather waiting on the government to come down and meet their needs. Continuous development of teachers is essential for any nation with the vision of improving its teachers' ability and capacity.

The government, teacher unions and other representative agencies make professional development decisions with no or little consultation on the part of the classroom teacher. Even though there is a general consent about the importance of teacher reflection, it could be argued that the professional development needs of teachers are decided just for the need to bring about particular change in the system, rather than to offer support for professional development of teachers.

Mean score of 2.15 and standard deviation of 1.20 also indicate that respondents are very much worried about the district's plan in implementing CPD programmes. They believe the district is not properly resourced and lacks long term plans sustainable enough for teachers' development on the job.

Most educational institutions are not self-sufficient; there are several problems in terms of human and financial resources. The Ministry of Education (2009) suggests that it is prudent for institutions organizing training programmes to fall on other experienced and experts from other organizations if they cannot find one in their midst.

The nature of previous training programmes according to the teachers who spoke to the researcher indicates that the district does not have long term plans in the area of CPD programmes. In an interview with head teachers of the participating schools, lamented about the district's posture in organizing CPDP's;

Respondent A:
The district education directorate does not take informed decisions about CPD programmes in the district. The posture of authorities suggests that they are not interested in updating teachers' knowledge on subject matter. They appear as if they lack the will to implement these programmes in the district.

\section{Respondent B:}

Monitoring by the GES office in the district, finance should be made available, rewards in cash or in kind should be given to teacher who participate in CPD's, teachers should be motivated to upgrade their knowledge and skills whilst on the job.

In response to another assertion, teachers revealed that they would have been very happy if CPD programmes were institutionalized and made compulsory for all teachers.

A mean score of 1.73 and a standard deviation of 1.00 confirmed this claim. This way according to the teachers will ensure parity in access that would go a long way to help teachers develop their competencies, knowledge, and skills. Continuous professional development of teachers is essential for any comprehensive education apparatus to thrive. It aims at improving on its manpower and capacity building.

Oluremi (2013) believed in the assertion that CPD programmes must be incorporated into the academic calendar and made compulsory in teacher training and preparation; this will place teachers in a better position to be aware of the need to attend training programmes which eventually will bring delight to the teachers and make them more committed to their jobs.

Also, a mean of 2.10 and a standard deviation of 1.25 indicated teachers' agreement to the fact that teachers must be granted study leave when their time is due. The bureaucracy that delays the process and in some instances denies teachers their rightful study leave periods must be properly looked at.

Conscious efforts must be made in opening up learning opportunities for teachers to upgrade their academic credentials; this will bring teachers up to speed with the ever changing world of teaching.

The researcher also wanted teachers to have a bite on the proposal that authorities must design and implement good policies and procedures to equip teachers with the right skills and knowledge required of them in the classroom. A mean of 2.05 and a standard deviation of 1.18 revealed that teachers agree to the assertion.

A mean score of 2.00 and a standard deviation of 1.04 indicated that majority of the respondents must be provided with time and opportunity to acquire knowledge from colleagues both within the workplace and outside the workplace. When the district brings together teachers for training, they interact and share relevant ideas that will improve their bearing in the classroom.

They are likely to discuss success and challenges alike regarding the teaching profession. This is in line with the believe of Lindstrom and Speck (2004), who highlighted the importance of Professional development; as a continual persistent practice of professional learning supported by current research and allows for suitable professional 
collaboration and knowledge sharing, based on current research to inform teachers' everyday routines. Institutions that neglect CPD programmes for teachers will pose a danger of making the teachers irrelevant as society grows by the day.

\section{CONCLUSION}

From the findings, it is concluded that even though teachers are aware of continuous professional development programmes and its unlimited importance, limited opportunities prevents them from updating their knowledge and competencies.

Even though governments' intervention is vital in the provision of CPD programmes, the district's involvement is key. The district is however not proactive in initiating its own CPD programmes, but rather waiting on government to address the inadequacy of CPD programmes.

It can also be concluded that CPD is a necessary prerequisite for the fast development of teacher's relevant work skills, and essential in developing the teacher's professional knowledge for better classroom of teaching and learning.

Similarly, when teachers attend CPD programmes, it updates their knowledge with new trends in the teaching profession, and positions them properly to deliver on the job independently.

In view of the fact that CPD is a positive tool for teachers' holistic development, it can be concluded that authorities must design and implement good policies and procedures to equip teachers with the right skills and knowledge, grant them study leave on time and encouraged to go for upgrading when their time is due, and provide teachers with time and opportunity to learn from peers on and off their workplace to enhance their knowledge, skills and competencies in teaching.

\section{RECOMMENDATIONS}

The District Education Directorate must design and implement a proper CPD programme that complements the efforts of NGOs that support teacher development in the Nanumba north district.

The Ghana Education Service should implement a thorough monitoring and evaluation of functional CPD programmes in the schools.

The GES must join hands with teacher unions to encourage all teachers to upgrade their teaching qualifications.

Also, GES must work hand in hand with stakeholders in taking a step further in making CPD programmes compulsory for all teachers.

It is also recommended that, Ghana Education Service must offer teachers study leaves to encourage them enroll on higher learning courses to upgrade their teaching qualification.

The District Education Directorate in collaboration with all school heads must encourage all teachers to share knowledge and to collaborate with colleagues on best practices in the field of teaching and learning.
The District Education Directorate must take conscious steps in hiring only competent facilitators to handle training programmes for teachers in the district. To ensure convenience, safe and effective supervision and monitoring in the schools, the District Education Directorate in conjunction with the District Assembly must ensure that there are good road networks in the district.

Last but not least, the District Education Directorate must work with all school heads to ensure that all training programmes are reviewed to be effective and more comprehensive in terms of time and duration.

\section{ACKNOWLEDGMENT}

We are thankful to God Almighty for the grace. We send also our appreciation to the following people for their immense support towards the success of this study; Mr. Abdul Rahaman Abdul Rauf, Miss Fatima, Mr. Louis, Mr. Mahama Awal and Mr. Shaddad Mahama Wunko.

\section{REFERENCES}

Acheampong, K. (2004). Whole school development in Ghana. 2005 Education For All (EFA) Monitoring Report Commissioned Study.

Adams, W. (2015). Conducting Semi-Structured Interviews. 10.1002/9781119171386.ch19.

Adu-Gyamfi, S., Donkoh, W. and Anim, A. A. (2016). Educational Reforms in Ghana: Past and Present. Journal of Education and Human Development, 5, 158-172.

Alliance for Excellent Education (2006). High school dropouts cost the U.S. Billions in lost wages and taxes, according to Alliance for Excellent Education [Press release]. Washington: Alliance for Excellent Education.http://www.all4ed.org/press/pr_022806.html

Atta, G. \& Mensah, E. (2015). Exploring Teachers' Perspectives on the Availability of Professional Development Programs: A Case of One District in Ghana. International Journal of Humanities and Social Science, 5(7),

Bredeson, P.V. (2003). Designs for learning. Thousand Oaks, CA: SAGE.

Coetzer, I. A. (2001). A survey and appraisal of outcomes-based education (OBE) in South Africa with reference to progressive education in America. Educare, 30,73-93.

Darling-Hammond, L., Chung, R., and Frelow, F. (2002). Variation in teacher preparation: How well do different pathways prepare teachers to teach? Journal of Teacher Education, 53(4), 286-302.

Day, C. \& Sachs, J. (2004). Professionalism, Performativity and Empowerment: Discourses in the Politics, Policies and Purposes of Continuing Professional Development. In Day, C., \& Sachs. J. (Eds.), International Handbook on the Continuing Professional Development of Teachers (pp. 3-32). Maidenhead: Open University Press.

Guskey, T. R. (2002). Professional Development and Teacher Change. Teachers and Teaching: Theory and Practice, 8, 381- 391. http://dx.doi.org/10.1080/135406002100000512

Hassan, D. A. (2013). Analysis of Professional Development Practices for School Teachers in Pakistan: A Comparative Case Study of Public and Private Schools of Pakistan (Punjab). International Journal of Human Resource Studies, 3(4).

Hattie, J. A. C. (2011). Which strategies best enhance teaching and learning in higher education? In Mashek, D., \& Hammer, E. (Eds.), Empirical research in teaching and learning: Contributions from social psychology (pp. 130 -142). Hoboken, NJ: Wiley-Blackwell. http://dx.doi.org/10.1002/9781444395341.ch8

Institute for Learning. (2009). 2008-09 IfL review of CPD: making a difference for teachers, trainers and learners. London: IfL.

Israel, M., Ribuffo, C., and Smith, S. J. (2014). Universal design for learning innovation configuration: Recommendations for preservice teacher preparation and in-service professional development. Gainesville, FL: CEEDAR, Center

Jarvis, S. \& Algozzine, B. (2006). Everything I need to know about Teaching: They Forgot To Tell Me! Thousand Oaks, CA: Corwin Press.

Lessing, A. \& De Witt, M. (2007). The value of continuous professional development: Teachers' perceptions. South African Journal of Education, 27 (1), 53-67. 
Lindstrom, P. H. \& Speck, M. (2004). The principal as professional development leader. Thousand Oaks, CA: Corwin.

Ministry of Education (2005). Education Statistics Annual Abstract 2003/2004. Addis Ababa: MoE

Ministry of Education (2009). Continuous Professional Development for Primary and Secondary School Teachers, Leaders and Supervisors in Ethiopia. Final draft, Addis Ababa.

Mohammed, I. (2015). Factors impacting on teachers' professionalism at secondary schools in the Elliotdale Circuit of the Dutywa Education District [Unpublished doctoral dissertation].

Moyle, K. (2007). How can the Value of Educational Technologies in Schools be Measured? Paper Presented At The World Conference On Educational Multimedia, Hypermedia \& Telecommunications, Vancouver: Canada.

National Education Association (2010). Preparing 21st Century Students for a Global Society: An Educator's Guide to the "Four Cs". http://www.nea.org/assets/docs/A-Guide-to-Four-Cs.pdf.

Ndeto, M. D. and Bwisa, H. M. (2013). Factors influencing teachers' active involvement in continuous professional development: A survey in Trans Nzoia West District, Kenya. International Journal of Academic Research in Business and Social Sciences, 3(5), 224-235.

Oluremi, D. F. (2013). Professional Development of Teachers in Africa: A Case Study of Nigeria. The African Symposium, 13(1).

Riehl, L. M., Shields, P. M., and Tiffany, J. (2000). Preparing and supporting new teachers: A literature review. Menlo Park, CA: SR International.

Shoqair, M. S. \& Shaaban, S. S. (2013). Strategies of Professional Development for EFL and Technology Teachers. Science Publishing Group Education Journal 2013, 2 (6), 249-255. http://www.sciencepublishinggroup.com/j/e du

Turner-Bisset, R. (2001). Expert Teaching: Knowledge and Pedagogy to Lead the Profession. London: David Fulton Publishers.

Wilson, S., Floden, R., and Ferrini-Mundy, J. (2001). Teacher preparation research: current knowledge, gaps, and recommendations. Center for the Study of Teaching and Policy, University of Washington. http://depts.washington.edu/ctpmail/PDFs/TeacherPrep-WFFM-022001.pdf

Mr. Alhassan Mahama is a lecturer at the Faculty of Education, University for Development Studies, UDS-Ghana. He holds an MPhil in Educational Training and Development and a Bachelor of Education in Social Science Education (Economics and Geography Options) all from the UDS.

$\mathrm{He}$ is at the moment the Quality Assurance Officer of the Faculty of Education, University for Development Studies, Ghana.

He has varied research interest including Training and Development of Staff, Human Resource Development and Policy issues in Education.

Dr. Issah Mohammed holds a $\mathrm{PhD}$ in Educational Administration from the University of KwaZulu Natal, Mthatha, South Africa. He is currently a Lecturer and Head of Department for the Business Education Studies Department, Faculty of Education, University for Development Studies, Ghana.

He researches into areas such as Professional Development, Human Resource Development and Educational Management.

Dr. Ibrahim Mohammed Gunu is a Senior Lecturer of Educational Administration and Policy Studies. He acquired a $\mathrm{PhD}$ from the University of Keele, UK. He is the current Dean of the Faculty of Education, University for Development Studies, Ghana.

$\mathrm{He}$ is a prolific writer and a Commonwealth Scholar. His research interest is into Educational Administration, Staff development and Planning, Human Resource Development and Policy Studies. 